\title{
THE OPEN WINDOW OF SUSCEPTIBILITY TO INFECTION AFTER ACUTE EXERCISE IN HEALTHY YOUNG MALE ELITE ATHLETES
}

Acute immune system response in elite cyclists

M.W. Kakanis ${ }^{1,3}$, J. Peake ${ }^{2,3}$, E.W. Brenu ${ }^{1}$, M. Simmonds ${ }^{1}$, B. Gray ${ }^{1}$, S.L. Hooper ${ }^{3}$, S.M. Marshall-Gradisnik ${ }^{1}$

1 Faculty of Health Sciences and Medicine, Bond University, Robina, Queensland, Australia

2 The University of Queensland, School of Human Movement Studies, Brisbane, Queensland, Australia

3 Centre of Excellence for Applied Sport Science Research, Queensland Academy of Sport, Sunnybank, Queensland, Australia

Address for correspondence:

Michael Kakanis, Faculty of Health Sciences and Medicine, Bond University, QLD, 4229, Australia, Email mkakanis@student.bond.edu.au, Tel +61 755954182

\begin{abstract}
The 'open window' theory is characterised by short term suppression of the immune system following an acute bout of endurance exercise. This window of opportunity may allow for an increase in susceptibility to upper respiratory illness (URI). Many studies have indicated a decrease in immune function in response to exercise. However, many studies do not indicate changes in immune function past 2 hours after the completion of exercise, consequently failing to determine whether these immune cells numbers, or importantly their function, return to resting levels before the start of another bout of exercise.
\end{abstract}


Ten male 'A' grade cyclists (age $24.2 \pm 5.3$ years; body mass $73.8 \pm 6.5 \mathrm{~kg}$; $\mathrm{VO}_{2 \max } 65.9 \pm 7.1$ $\mathrm{mL} \cdot \mathrm{kg}^{-1} \cdot \mathrm{min}^{-1}$ ) exercised for two hours at $90 \%$ of their second ventilatory threshold. Blood samples were collected pre-, immediately post-, 2 hours, 4 hours, 6 hours, 8 hours, and 24 hours post-exercise. Immune variables examined included total leukocyte counts, neutrophil function (oxidative burst and phagocytic function), lymphocyte subset counts $\left(\mathrm{CD} 4^{+}, \mathrm{CD}^{+}\right.$, and $\mathrm{CD} 16^{+} / 56^{+}$), natural killer cell activity (NKCA), and $\mathrm{NK}$ phenotypes (CD56 ${ }^{\mathrm{dim}} \mathrm{CD} 16^{+}$, and CD56 $\left.{ }^{\text {bright }} \mathrm{CD} 16^{-}\right)$.

There was a significant increase in total lymphocyte numbers from pre-, to immediately postexercise $(\mathrm{p}<0.01)$, followed by a significant decrease at 2 hours post-exercise $(\mathrm{p}<0.001)$. CD4 ${ }^{+}$ T-cell counts significantly increased from pre-exercise, to 4 hours post- $(\mathrm{p}<0.05)$, and 6 hours post-exercise $(\mathrm{p}<0.01)$. However, NK $\left(\mathrm{CD}^{+} 6^{+} / 56^{+}\right)$cell numbers decreased significantly from pre-exercise to $4 \mathrm{~h}$ post-exercise $(\mathrm{p}<0.05)$, to $6 \mathrm{~h}$ post-exercise $(\mathrm{p}<0.05)$, and to $8 \mathrm{~h}$ post-exercise $(\mathrm{p}<0.01)$. In contrast, CD56 ${ }^{\text {bright }} \mathrm{CD} 16^{-} \mathrm{NK}$ cell counts significantly increased from pre-exercise to immediately post-exercise $(\mathrm{p}<0.01)$. Neutrophil oxidative burst activity did not significantly change in response to exercise, while neutrophil cell counts significantly increased from preexercise, to immediately post-exercise $(\mathrm{p}<0.05)$, and 2 hours post-exercise $(\mathrm{p}<0.01)$, and remained significantly above pre-exercise levels to 8 hours post-exercise $(p<0.01)$. Neutrophil phagocytic function significantly decreased from 2 hours post-exercise, to 6 hours post- $(\mathrm{p}<0.05)$, and 24 hours post-exercise $(\mathrm{p}<0.05)$. Finally, eosinophil cell counts significantly increased from 2 hours post to 6 hours post- $(\mathrm{p}<0.05)$, and 8 hours post-exercise $(\mathrm{p}<0.05)$.

This is the first study to show changes in immunological variables up to 8 hours post-exercise, including significant NK cell suppression, NK cell phenotype changes, a significant increase in total lymphocyte counts, and a significant increase in eosinophil cell counts all at 8 hours postexercise. Suppression of total lymphocyte counts, NK cell counts and neutrophil phagocytic function following exercise may be important in the increased rate of URI in response to regular intense endurance training.

Key words: natural killer cells, NK phenotype, lymphocytes, neutrophils, eosinophils, exercise immunology 


\section{Introduction}

Monitoring the immune system of athletes has become an important part of the preparation for competition, which also includes training, recovery, nutrition, and psychology. Because interruptions in training due to illness can dramatically influence the preparation and competitive program of an elite athlete, complete management of an athlete's preparation is needed to ensure optimum performance.

Of particular interest is endurance exercise, in which high volumes of training (commonly associated with such events) can increase the risk of illness. The incidence of upper respiratory illness (URI) in both highly trained and healthy untrained individuals is known to increase in response to increases in activity, whether it is during competition (39), or during heavy training blocks (16).

This risk of illness in response to exercise has been modelled by the ' $J$ ' Curve (29). This model suggests that individuals engaging in moderate physical activity are at lower risk of illness compared with sedentary individuals (24). Conversely, excessive volumes of strenuous endurance exercise may suppress immune function, thereby increasing the risk of illness $(9,10$, $16,23)$.

Exercise immunology studies can be sub-divided into one of two categories, epidemiological studies comparing the incidence of URI during periods of intensive training (16, 23), and studies measuring various aspects of cellular immunity in response to exercise. These studies of the cellular immune system may include measurements of the following: total white cell counts and white cell subset concentrations (neutrophils, lymphocytes, monocytes, eosinophils, basophils) $(8,13,41,43)$; lymphocyte subsets (natural killer cells, B-cells, T-cells); various cell functional measurements including; neutrophil oxidative burst $(8,20,22,45)$, phagocytic function $(13,41$, 45), lymphocyte proliferation (46), and natural killer cell cytotoxic activity $(30,31,42)$ ), natural killer cell phenotype (14); and various Immunoglobulins ( $\operatorname{IgA} / \operatorname{IgM} / \operatorname{IgD} / \operatorname{IgE} / \operatorname{IgG})(15,16)$.

In monitoring the changes in humoral and cellular immune variables linked with an increased occurrence of illness following endurance exercise, it has been proposed that following an acute bout of endurance exercise, suppression of some immune variables may make the host more 
susceptible to micro-organisms which have entered the body (34). In turn, this may increase the risk of URI. This concept is known as the 'Open Window' Theory.

Of the many exercise immunology studies involving endurance exercise mentioned above, there is a common pattern in sampling for the various immune variables. Many studies include preexercise resting levels and immediately post-exercise $(8,14,31)$, plus 1 or $2 \mathrm{~h}$ post-exercise $(20$, $21,30)$, and on occasion a $24 \mathrm{~h}$ sample (41). Few studies include samples at 2 or $3 \mathrm{~h}$ postexercise $(13,43)$, and no other study goes beyond that at regular time points following endurance exercise. Between $2 \mathrm{~h}$ to $24 \mathrm{~h}$ after exercise, there are very limited data concerning the immune changes that occur during this period. This is of particular importance, because some immune parameters do not return to resting levels within $2 \mathrm{~h}$ after exercise. Therefore, it is unknown when immune function returns to normal, and when it is safe to return to training.

Exercise protocols in previous studies investigating the effects of endurance exercise on the immune system have varied dramatically. This variability causes difficulty in comparing between studies. Some studies accurately represent stress on the body of elite competition or

training $(8,13,14,21,30)$, but many studies fail to simulate the duration or intensity of elite endurance training or competition $(18,22,42)$.

The current study aimed to address some of the limitations of previous studies by increasing sampling points (including pre-exercise, immediately post-exercise, 2 hours, 4 hours, 6 hours, 8 hours, and 24 hours post-exercise), using a strenuous endurance exercise protocol of 2 hours at $90 \%$ of the subjects second ventilatory threshold (about $70-80 \% \quad \mathrm{VO}_{2 \max }$ ), and monitoring the immune system to determine in the function of immune cells at time points beyond 2 hours after exercise. Hence, this project provides detailed insight into the acute effects of exercise on immune function.

\section{Materials and Methods}

Subjects

Ethical clearance for this study was obtained from the Bond University Human Research Ethics Committee (RO955). Ten elite 'A' grade club level male cyclists were recruited from various 
cycling and triathlon clubs in South/East Queensland through Cycling Australia and Triathlon Australia (Table 1). Selection of cyclists was based on a questionnaire and $\mathrm{VO}_{2 \text { peak }}$ test. Before any testing, subjects completed and signed a consent form, a health questionnaire (including PAR-Q), and a training questionnaire.

\section{Table 1: Descriptive characteristics of subjects}

Male 'A' grade cyclists $(\mathrm{n}=10)$

\begin{tabular}{lcc}
\hline & Mean & SD \\
\hline Age (years) & 24.2 & 5.3 \\
Height $(\mathrm{m})$ & 1.82 & 0.07 \\
Body mass $(\mathrm{kg})$ & 73.8 & 6.5 \\
BMI & 22.2 & 1.1 \\
Absolute $\mathrm{VO}_{\text {2peak }}\left(\mathrm{L} \cdot \mathrm{min}^{-1}\right)$ & 4.8 & 0.3 \\
Relative $\mathrm{VO}_{\text {2peak }}\left(\mathrm{mL} \cdot \mathrm{kg}^{-1} \cdot \mathrm{min}^{-1}\right)$ & 65.9 & 7.1 \\
Training $(\mathrm{km} /$ week $)$ & 292.5 & 89.8 \\
\hline
\end{tabular}

Data above are expressed in mean $\pm \mathrm{SD}$

\section{Exercise Protocol}

Subjects visited the exercise laboratory on three separate occasions for testing: a familiarisation session, a $\mathrm{VO}_{2 \text { peak }}$ test, and an experimental trial involving $2 \mathrm{~h}$ cycling at $90 \%$ of the subject's second ventilatory threshold $\left(\mathrm{T}_{\mathrm{V} 2}\right)$ where blood samples were taken before, immediately post-, 2 h, $4 \mathrm{~h}, 6 \mathrm{~h}, 8 \mathrm{~h}$, and $24 \mathrm{~h}$ post-exercise.

In the familiarisation session, each subject completed the three questionnaires, and their height (Harpenden Stadiometer, Holtain Limited, Crymych, United Kingdom), body mass (BC-548, Tanita, Illinois, USA), age, and blood pressure at rest (Standby® Model, Baumanometer, New York, USA) were recorded. Heart rate at rest was taken using a 12-lead electrocardiogram (ECG) (Mortara X Scribe, Wisconsin, USA). Each subject proceeded to be familiarised with the experimental protocols and procedures. This involved the subject performing the first $\mathrm{X}$ stages of the $\mathrm{VO}_{\text {2peak }}$ protocol until the point that the subject's heart rate reached $120 \mathrm{bpm}$, when the familiarisation protocol was terminated by the investigators. 
After 3 days, the subjects returned for the $\mathrm{VO}_{2 \text { peak }}$ test session. The subject's body mass, and blood pressure at rest were measured. Heart rate was monitored using a 12-lead ECG. $\mathrm{VO}_{2 \text { peak }}$ was determined using a graded maximal protocol (30 watt increase every minute starting at 80 Watts) until the test was terminated by the subject or a $\mathrm{VO}_{2}$ plateau was reached. The test was performed on an electromagnetically braked cycle ergometer (Lode Excallibur Sport, Groningen, Netherlands).

Before cycling for $2 \mathrm{~h}$ cycle at $90 \%$ second ventilator threshold $\left(\mathrm{T}_{\mathrm{V} 2}\right)$, each subject prepared in the same manner described above for the $\mathrm{VO}_{2 \text { peak }}$ test session. In addition, pre-exercise blood and saliva samples were taken from subjects who had undergone an overnight fast. Subjects then consumed a standardised breakfast of cereal, milk, and juice and began exercise at 0800. The subject completed the protocol on a training cycle ergometer (Monark Ergomedic 828 E, Sweden). Heart rate sampling was conducted every minute, and gas exchange at 20 minute intervals to ensure that the subject maintained the correct exercise intensity. If oxygen consumption was at an incorrect output, power output was altered until corrected. Gas exchange was measured for 4 minutes to ensure the oxygen consumption was consistent. Ingestion of water was permitted during exercise. Once finished, subjects were fed, however they were not permitted to eat 1 hour before each saliva and blood sample. Subjects were not permitted to exercise or consume alcohol between pre-exercise and 24 hours post-exercise samples.

\section{Determination of second ventilatory threshold}

Each subject's second ventilatory threshold ( $\left.\mathrm{T}_{\mathrm{V} 2}\right)$ was determined from his $\mathrm{VO}_{2 \text { peak. }} \mathrm{T}_{\mathrm{V} 2}$ was defined by a secondary rise in $\mathrm{V}_{\mathrm{E}}$ and $\mathrm{V}_{\mathrm{E}} \cdot \mathrm{VO}_{2}{ }^{-1}$, and a marked increase in the ventilatory equivalent for $\mathrm{CO}_{2}\left(\mathrm{~V}_{\mathrm{E}} \cdot \mathrm{V}_{\mathrm{CO}_{2}}{ }^{-1}\right)$ and decrease in the fraction of expired $\mathrm{CO}_{2}\left(\mathrm{~F}_{\mathrm{E}} \mathrm{CO}_{2}\right)$ during exercise above the first ventilatory threshold (11). 


\section{Sample Collection}

Blood samples were collected at each time point (see Figure 1) during the day of the $2 \mathrm{~h}$ cycle at 90\% $\mathrm{T}_{\mathrm{V} 2}$ test. A qualified phlebotomist collected the blood sample at each time point from an antecubital vein. At each of seven time points, $43.5 \mathrm{~mL}$ of blood was taken, totalling $304.5 \mathrm{~mL}$.

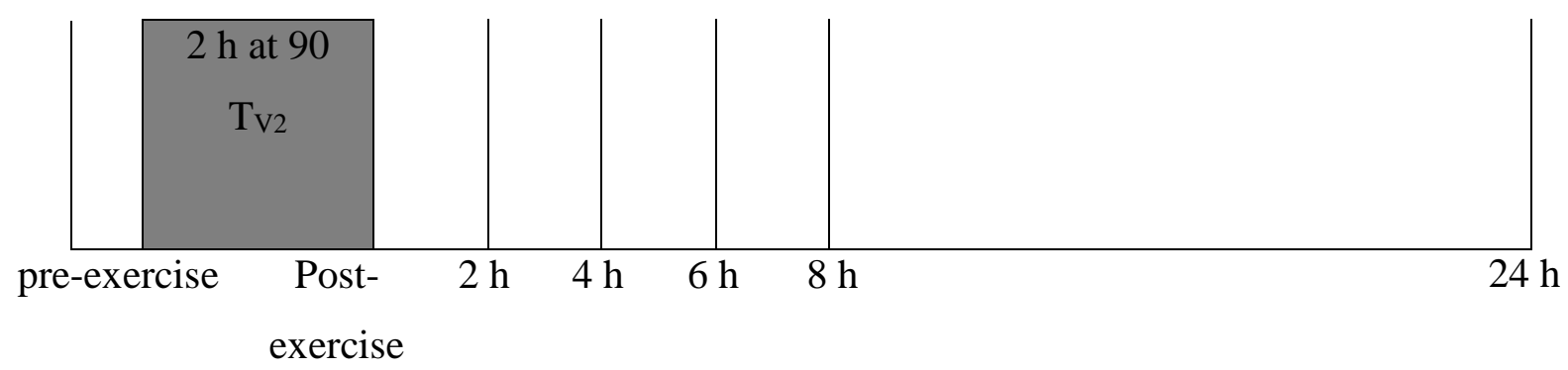

Figure 1: Blood sampling schedule for $2 \mathrm{~h}$ cycle test

Assessment of Lymphocyte Subsets

Lymphocytes were assessed using the Simultest ${ }^{\mathrm{TM}}$ IMK-Lymphocyte kit (Becton Dickson (BD) Bioscience, California, USA). The Simultest ${ }^{\mathrm{TM}}$ IMK-Lymphocyte kit quantitatively and qualitatively measures the number of lymphocytes in the blood. This method has been used for the quantifying of peripheral blood lymphocytes. This kit includes reagents containing fluorescein isothiocyanate (FITC) and phycoerythrin (PE) conjugated antibodies (mAbs) specific for T (CD4/CD8), B (CD19), and NK (CD16/CD56) lymphocytes. Samples were analysed according to the manufacturer's instructions. Briefly, in six separate tubes, $100 \mu \mathrm{L}$ of blood (collected in EDTA anti-coagulation blood collection tubes) (BD Vacutainer, New Jersey, USA) were mixed with $20 \mu \mathrm{L}$ of each of six reagents (BD Bioscience) containing mAbs to identify lymphocyte subsets. Samples were then incubated for 20 minutes at room temperature in the dark. Next, $2 \mathrm{~mL}$ of lysing solution (BD Bioscience) were added and samples were incubated (Grant W14, Massachusetts, USA) for 10 minutes at room temperature in the dark. Immediately after incubation, tubes were centrifuged (Thermo Scientific, Massachusetts, USA) at $300 \times g$ for 5 minutes. The supernatant was removed. Samples were twice washed with phosphate buffer saline (PBS (Iso-Wash, Kinetik, Queensland, Australia) and centrifuged for 5 minutes at $200 \times g$, 
and the supernatant was removed at the end of each step. Finally, $500 \mu \mathrm{L}$ of $1 \%$ paraformaldehyde were added to each tube. Flow cytometric analysis (BD FACS Calibur, New Jersey, USA) was performed using the IMK acquisition and analysis protocol specific for T, B, and NK lymphocytes, where a total of 5000 events were counted.

\section{Phagocytic Function Assay}

Oxidative burst activity was measured using Phagotest ${ }^{\circledR}$ (Orpegen Pharma GmbH, Heidelberg, Germany) according to the manufacturer's instructions. This kit has been used for quantifying neutrophil phagocytic function in previous exercise immunology studies $(13,41)$. Phagocytic function was measured using $50 \mu \mathrm{L}$ of lithium heparinised (BD Vacutainer) whole blood mixed with $10 \mu \mathrm{L}$ FITC-labelled opsonized E. coli bacteria (Orpegen Pharma) (adjusted according to polymorphonuclear leukocyte (PMN) cell concentration before the assay was started) and incubated for 10 minutes at $37^{\circ} \mathrm{C}$ (sample) or on ice (control). Next, $50 \mu \mathrm{L}$ of quenching solution (Orpegen Pharma) was added to remove FITC. Samples were then washed in $2 \mathrm{~mL}$ PBS and centrifuged at $1000 \times g$ for 2 minutes. The supernatant was then removed, and the same washing step was repeated. Samples were then lysed with 2 mL FACSLyse solution (BD Bioscience) and incubated for 10 minutes at room temperature in the dark. Samples were then centrifuged at 1000 $\times g$ for 2 minutes, the supernatant was removed, and the washing step was repeated. Finally, 100 $\mu \mathrm{L}$ of DNA staining solution (Orpegen Pharma) were added to all tubes and the tubes were incubated for 10 minutes at room temperature in the dark. Samples were then resuspended in 350 $\mu \mathrm{L}$ of PBS. Analysis was performed by flow cytometry (BD FACS Calibur) using the Phagotest acquisition protocol. All events with a higher fluorescence intensity (FI) than that of the negative control were defined as phagocytosing cells, and were expressed as the percentages of the total granulocytes; the mean FI of the positive peak (phagocytosing granulocytes) correlates with the number of phagocytosed bacteria per cell.

Oxidative Burst Assay 
Oxidative burst activity was measured using the Bursttest (Phagoburst ${ }^{\circledR}$ ) $($ Orpegen Pharma $\mathrm{GmbH}$, Heidelberg, Germany), as specified by the manufacturer. The Bursttest kit has been used for quantifying neutrophil oxidative burst activity in previous research (3). For all samples (Stimulated, Control, Unstimulated), $900 \mu \mathrm{L}$ of PBS were added to $100 \mu \mathrm{L}$ of lithium heparinised whole blood (BD Vacutainer), followed by $10 \mu \mathrm{L}$ of Phorbol 12-myristate 13-acetate (PMA) (Orpegen Pharma) (into tubes; Stimulated (includes all reagents) and Unstimulated (all reagents except Dihydrorhodamine (DHR)) and incubated in a bath at $37^{\circ} \mathrm{C}$. After 15 minutes of incubation, $10 \mu \mathrm{L}$ of DHR (Orpegen Pharma) were added into Stimulated tube and incubation of all tubes at $37^{\circ} \mathrm{C}$ (Grant W14) for 15 minutes was repeated. Samples were then centrifuged at $1000 \times g$ for 2 minutes, and the supernatant was removed. Next, $1 \mathrm{~mL}$ of $\mathrm{NH}_{4} \mathrm{Cl}$ lyse solution (BD Bioscience) were added, and all samples were incubated for 5 minutes at $37^{\circ} \mathrm{C}$. Samples were then centrifuged for 2 minutes at $1000 \times g$, the supernatant was removed, and $2 \mathrm{~mL}$ of PBS were added. The samples were again centrifuged at $1000 \times g$ for 2 minutes, and the supernatant was removed. Finally, all samples were resuspended in $500 \mu \mathrm{L}$ of paraformaldehyde and analysed using the FACS Calibur (Becton Dickinson) flow cytometer. The percentage of cells producing reactive oxygen radicals were analysed, and their mean fluorescence intensity recorded.

\section{Natural Killer Cell Phenotype Assay}

Analysis was performed by flow cytometry using the NK phenotype acquisition protocol. Negative selection of NK cells with the use of micro-beads was performed using the RosetteSep ${ }^{\circledR}$ Human Natural Killer cell Enrichment Cocktail (StemCell Technologies). To $3 \mathrm{~mL}$ of lithium heparinised blood, $150 \mu \mathrm{L}$ of RosetteSep cocktail solution were added, and the samples were then mixed and incubated at room temperature for 20 minutes. NK cells were then obtained by density gradient configuration using Ficoll-Hypaque (GE Healthcare, Wisconsin, USA) according to the manufacturer's instructions by layering $3 \mathrm{~mL}$ of the blood/RosetteSep solution onto $3 \mathrm{~mL}$ of Ficoll-Hypaque. Samples were then centrifuged at $1200 \times g$ for 30 minutes. The white cell layer was then removed and resuspended in $2 \mathrm{~mL}$ of PBS and centrifuged for 10 minutes at $400 \times g$. The supernatant was removed and $2 \mathrm{~mL}$ of PBS were added before 
centrifuging at $400 \times g$ for 5 minutes. The supernatant was removed, and $20 \mu \mathrm{L}$ of mAb CD56FITC (BD Bioscience) and CD16-PE (BD Bioscience) were added to all samples. The samples were then incubated on ice for 15 minutes, and resuspended in $1 \mathrm{~mL}$ of $1 \%$ formalin, after which they were analysed using the flow cytometer (BD FACS Calibur). A total of 10,000 events were counted.

\section{NK Lymphocyte Cytotoxic Activity Assay}

White blood cells were isolated from whole blood using Ficoll-Hypaque by layering $7 \mathrm{~mL}$ of whole blood collected from lithium heparinised blood collection tubes (BD Vacutainer) on top of $7 \mathrm{~mL}$ of Ficoll-Hypaque. Samples were then centrifuged for 30 minutes at $700 \times g$. The white blood cell layer was then removed and washed in PBS (Iso-Wash, Kinetik) twice, centrifuged at $700 \times g$ for 10 minutes, then $400 \times g$ for 5 minutes, and the supernatant was removed. Cells were then resuspended in diluent $\mathrm{C}$ solution (Sigma-Aldrich, Missouri, USA). $1 \mathrm{~mL}$ of PKH-26 fluorescent cell linker dye was then added and allowed to stain for 5 minutes at room temperature. $2 \mathrm{~mL}$ of serum solution were then added to stop the reaction, and the samples were incubated at room temperature for 1 minute. Cells were then washed twice (centrifuged at $400 \times$ $g$ for 5 minutes) and resuspended at a concentration of $5 \times 10^{6}$ cells $/ \mathrm{mL}$.

K562 cell lines were used as target cells for the NKCA assay. Before analysis, K562 cells were thawed and added to $50 \%$ fetal bovine serum and 50\% complete culture medium. Cells were then placed in an incubator (Sanyo $\mathrm{CO}_{2}$ Incubator, Leicestershire, UK) at $37^{\circ} \mathrm{C}$ and $5 \%$ for $24-36 \mathrm{~h}$. Cells were then centrifuged at $125 \times g$ for 5 minutes and resuspended in complete culture medium at a concentration of $1 \times 10^{5}$ cells $/ \mathrm{mL}$.

NKCA was performed as previously described by (2). NK (effector) cells and K562 (target) cells were mixed at a ratio of 25:1; control samples comprised only K562 (target) cells. Samples were then centrifuged for 5 minutes at $50 \times g$ and incubated at $37^{\circ} \mathrm{C}$ for 4.5 hours. Samples were then centrifuged ( $400 \times g$ for 5 minutes) and $5 \mu \mathrm{L}$ of Annexin V-FITC (BD Bioscience), $5 \mu \mathrm{L}$ of 7AAD (BD Bioscience), and $500 \mu \mathrm{L}$ of Annexin V binding buffer solution (BD Bioscience) were added to each tube. The samples were then incubated for 15 minutes at room temperature, and 
then analysed using the flow cytometer (BD FACS Calibur), in which a total of 10,000 events were counted.

\section{Full Blood Counts}

Full blood counts were performed using a five-part differential haematology analyser (Beckman Coulter AcT 5 diff AL Hematology Analyzer, California, USA). The haematology analyser uses a sequential dilution system and dual-focused flow fluid dynamics technologies employing the Coulter Principle of impedance to count and size the cells.

\section{Statistical Analysis}

All statistical analysis was performed using SPSS (version 17). Data at each time point were compared using one-way repeated measures ANOVA with the Bonferroni correction. The results are presented as the mean and standard error of the mean (SEM). The criterion for significance was set at $\mathrm{p}<0.05$.

\section{Results}

Significant post-exercise increases were measured for blood counts of total neutrophils and lymphocytes (Figure 2 and Figure 5) immediately post-exercise.

A significant decrease was found in neutrophil phagocytic function (Figure 3 ) from $2 \mathrm{~h}$ postexercise to $6 \mathrm{~h}$ and $24 \mathrm{~h}$ post-exercise, whereas neutrophil oxidative burst activity (Figure 4) remained unchanged.

Lymphocyte subset data are summarised in (Figure 6 and Figure 7). A significant increase was measured in $\mathrm{CD}^{+}$cells from pre-exercise to $4 \mathrm{~h}$ and $6 \mathrm{~h}$ post-exercise, whereas no change was seen in $\mathrm{CD}^{+}$cells. 
NK cell counts significantly decreased in response to exercise (Figure 8) from pre-exercise to $4 \mathrm{~h}$, $6 \mathrm{~h}$, and $8 \mathrm{~h}$ post-exercise, however NKCA remained unchanged (Figure 9). NK phenotype data are summarised in (Figure 10), where there was a significant increase in $\mathrm{CD} 56^{\text {bright }} \mathrm{CD} 16^{-} \mathrm{NK}$ cells from pre- to immediately post-exercise, but there was no change in $\mathrm{CD} 56{ }^{\mathrm{dim}} \mathrm{CD} 16^{+} \mathrm{NK}$ cells.

Eosinophil counts significantly increased (Figure 11) from $2 \mathrm{~h}$ and $4 \mathrm{~h}$ post-exercise, to $6 \mathrm{~h}$ and 8 $\mathrm{h}$ post-exercise.

Neutrophil Concentration

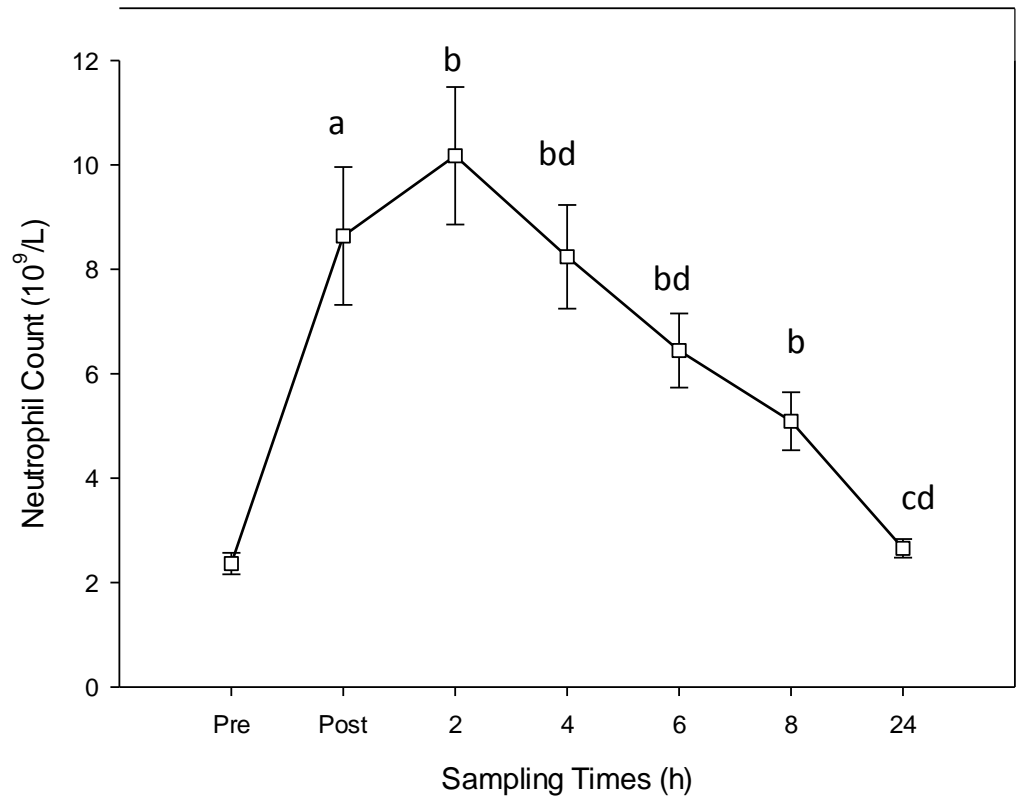

Figure 2: Changes in neutrophil concentrations in response to an acute bout of exercise, a $(\mathrm{p}<0.05)$ Pre-exercise - Immediately post-exercise; $b(\mathrm{p}<0.01)$ Pre-exercise $-2 \mathrm{~h}, 4 \mathrm{~h}, 6 \mathrm{~h}, 8 \mathrm{~h}$ post-exercise; $\mathrm{c} \quad(\mathrm{p}<0.05)$ Immediately post-exercise $-24 \mathrm{~h}$ post-exercise; $\mathrm{c} \quad(\mathrm{p}<0.01)$ Immediately post-exercise $-8 \mathrm{~h}, 24 \mathrm{~h}$ post-exercise.

Neutrophil Phagocytic Function 


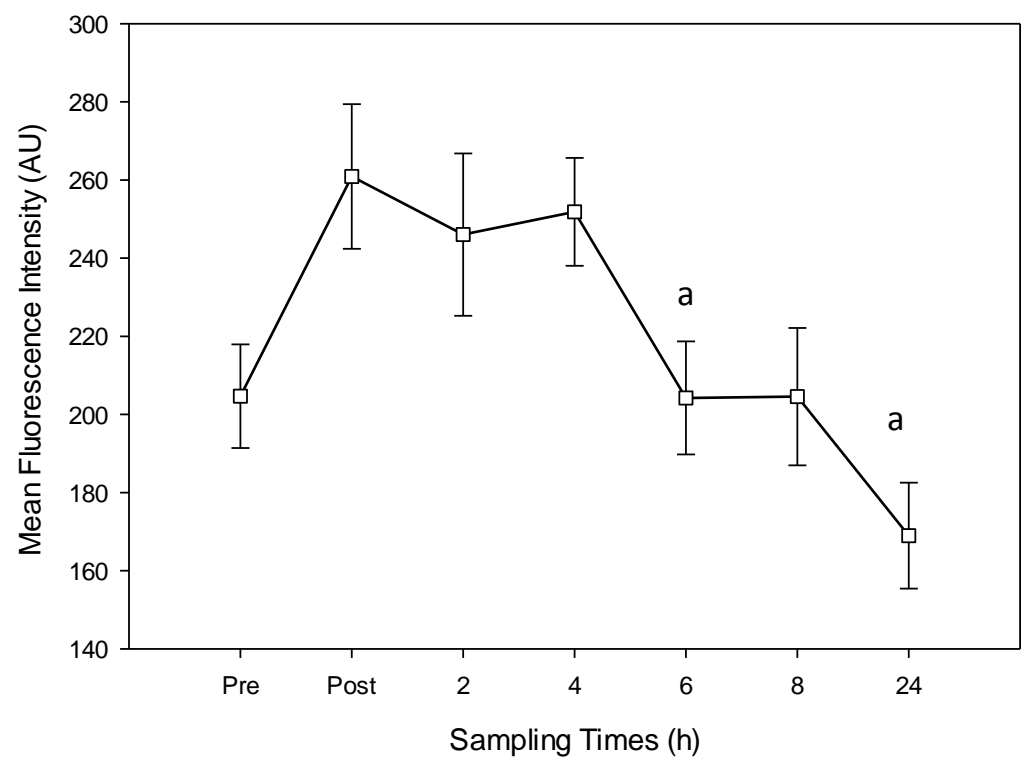

Figure 3: Changes in neutrophil phagocytic function in response to an acute bout of exercise, $\mathrm{a}(\mathrm{p}<0.05) 2 \mathrm{~h}$ post-exercise $-6 \mathrm{~h}, 24 \mathrm{~h}$ post-exercise.

Neutrophil Oxidative Burst

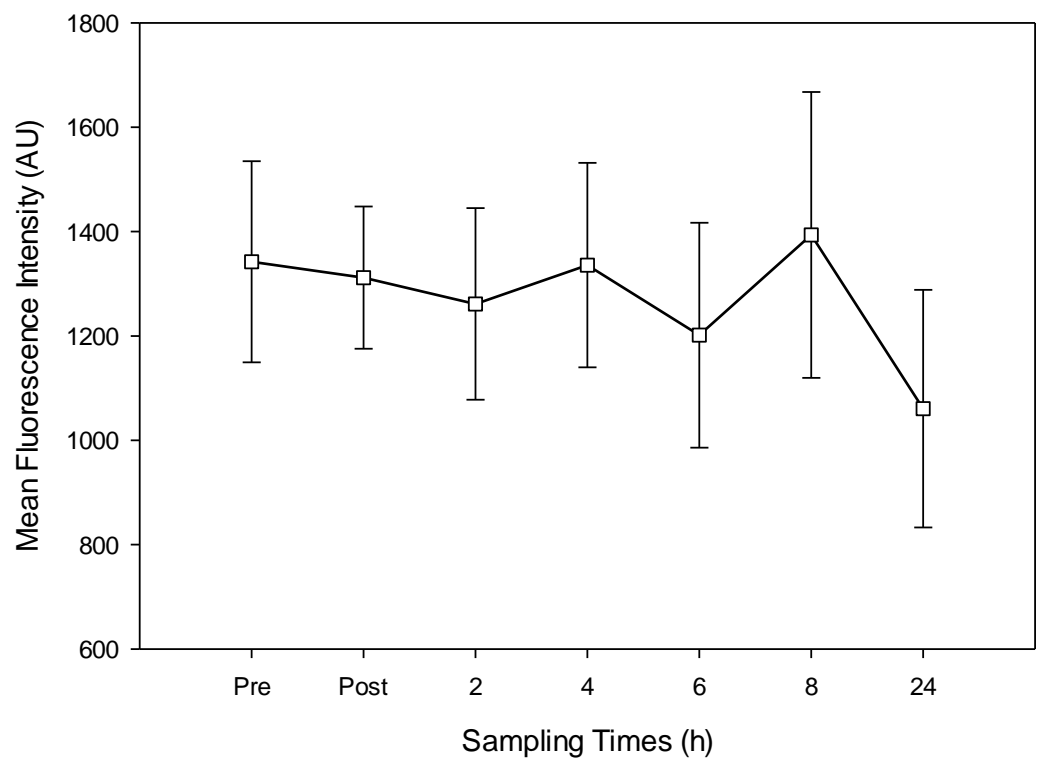

Figure 4: Changes in neutrophil oxidative burst function in response to an acute bout of exercise

Lymphocyte Concentration 


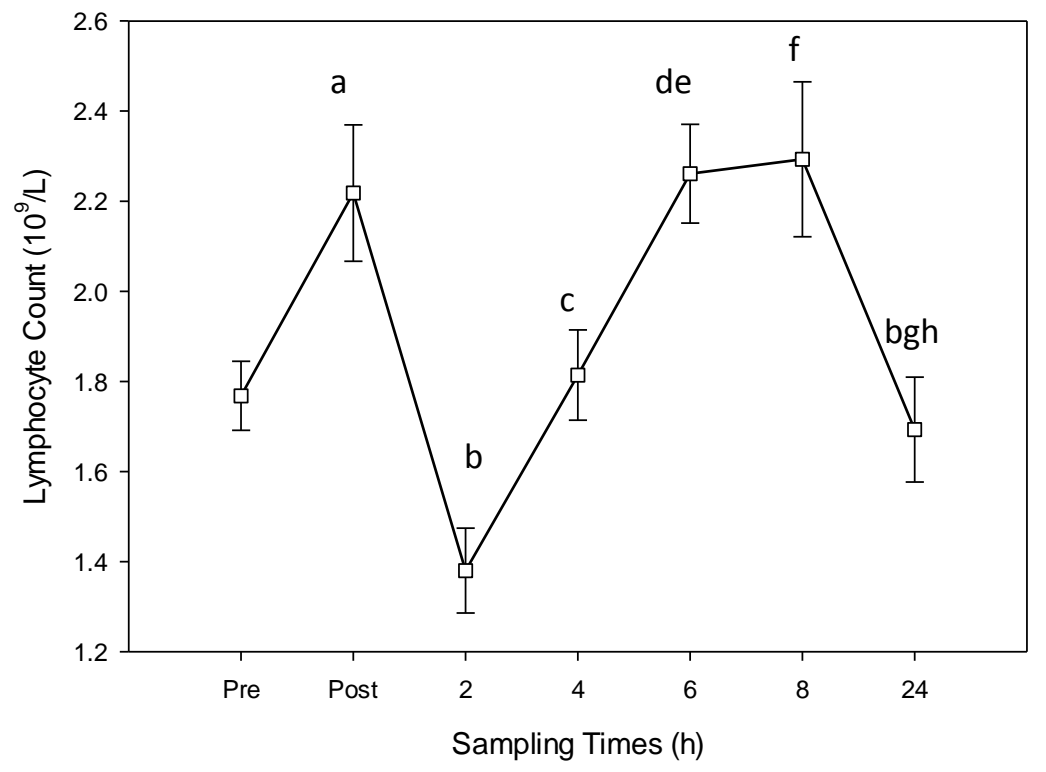

Figure 5: Changes in lymphocyte concentrations in response to an acute bout of exercise, a $(p<0.01)$ Pre-exercise - Immediately post-exercise; $b(p<0.001)$ Immediately post-exercise -2 h, 24 h post-exercise; c $(\mathrm{p}<0.01) 2 \mathrm{~h}$ post-exercise $-4 \mathrm{~h}, 8 \mathrm{~h}$ post-exercise; $\mathrm{d}(\mathrm{p}<0.001) 2 \mathrm{~h}$ postexercise $-6 \mathrm{~h}$ post-exercise; e $(\mathrm{p}<0.01) 4 \mathrm{~h}$ post-exercise $-6 \mathrm{~h}$ post-exercise; $\mathrm{f}(\mathrm{p}<0.05) 4 \mathrm{~h}$ postexercise $-8 \mathrm{~h}$ post-exercise; $\mathrm{g}(\mathrm{p}<0.01) 6 \mathrm{~h}$ post-exercise $-24 \mathrm{~h}$ post-exercise; $\mathrm{h}(\mathrm{p}<0.05) 8 \mathrm{~h}$ post-exercise $-24 \mathrm{~h}$ post-exercise.

$\mathrm{CD}^{+}{ }^{+}$T-cells 


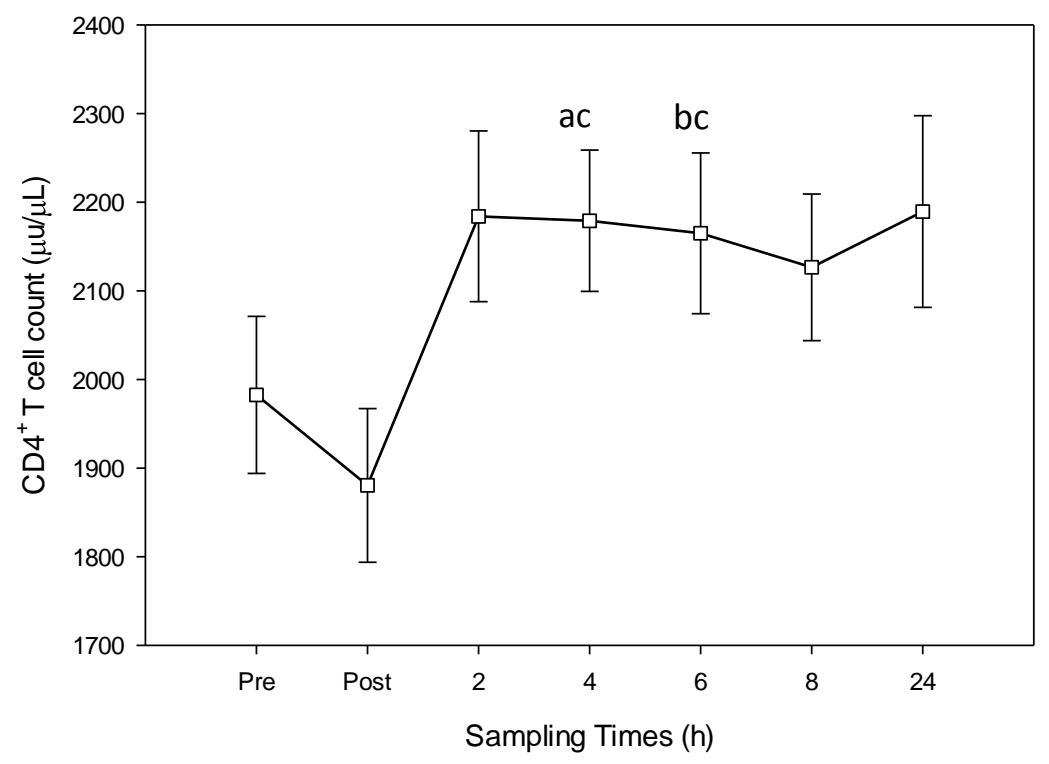

Figure 6: Changes in $\mathrm{CD}^{+} \mathrm{T}$-cell concentration in response to an acute bout of exercise, $\mathrm{a}(\mathrm{p}<0.05)$ Pre-exercise $-4 \mathrm{~h}$ post-exercise; $\mathrm{b}(\mathrm{p}<0.01)$ Pre-exercise $-6 \mathrm{~h}$ post-exercise; $\mathrm{c}$ $(\mathrm{p}<0.05)$ Immediately post-exercise $-4 \mathrm{~h}, 6 \mathrm{~h}$ post-exercise.

\section{$\mathrm{CD}^{+}$T-cells}

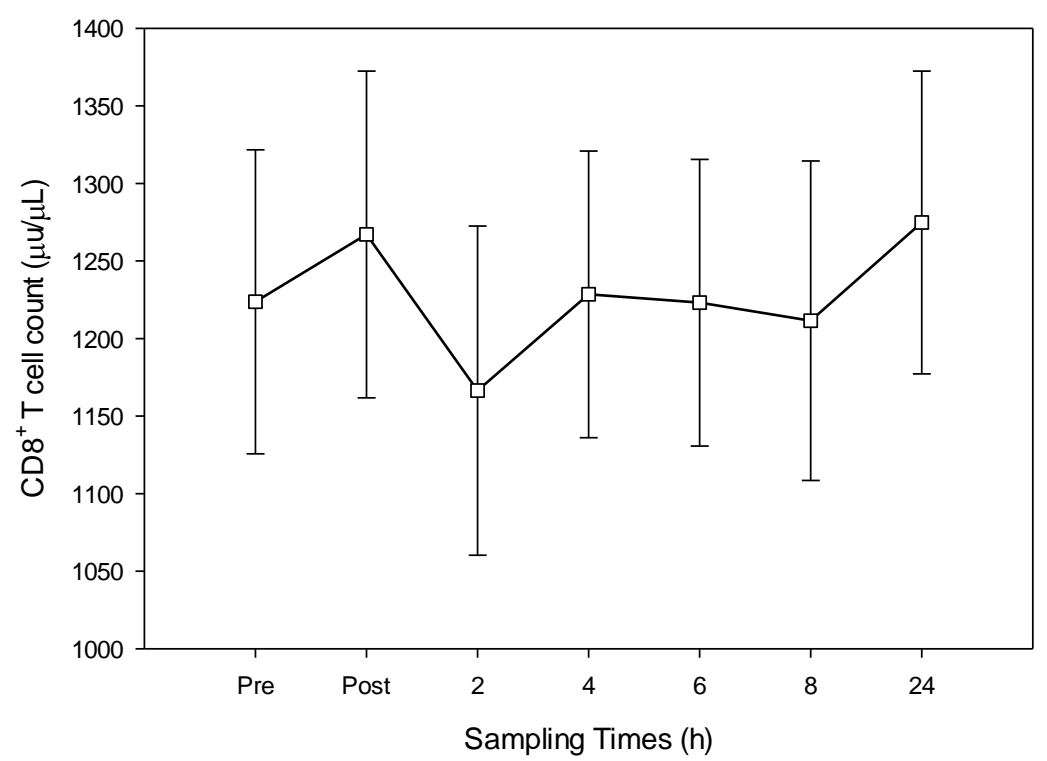

Figure 7: Changes in $\mathrm{CD}^{+} \mathrm{T}$-cell numbers in response to an acute bout of exercise 
Natural Killer Cell Concentration

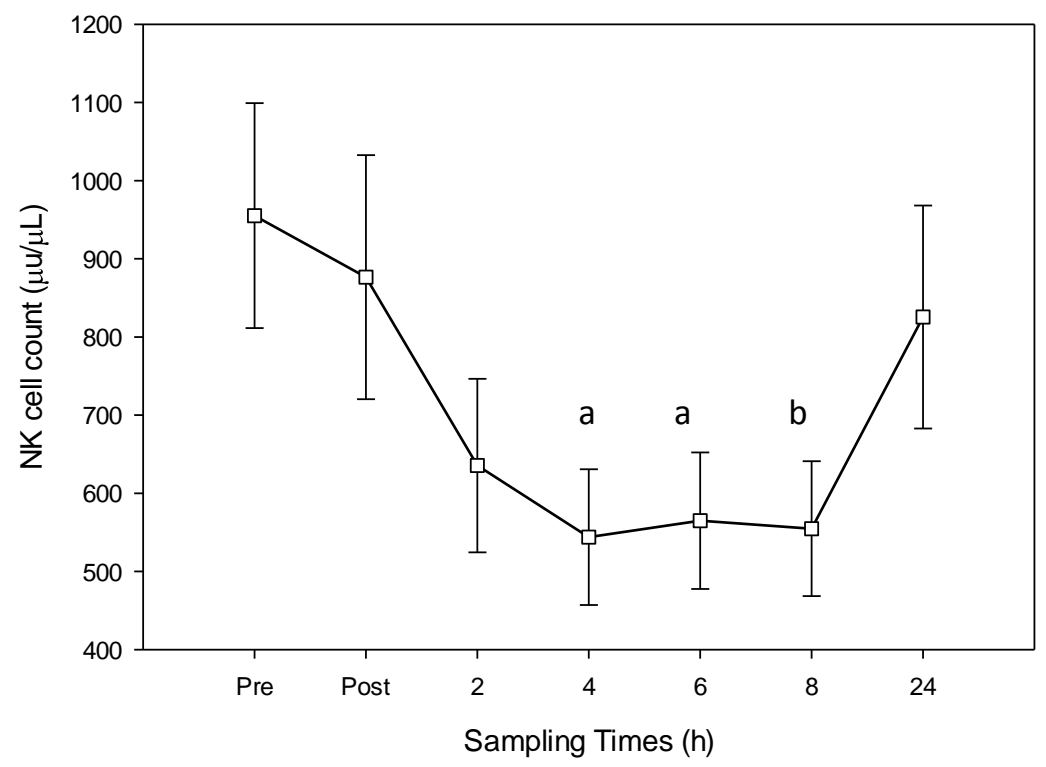

Figure 8: Changes in NK cell numbers in response to an acute bout of exercise, $\mathrm{a}(\mathrm{p}<0.05)$ Pre-exercise $-4 \mathrm{~h}, 6 \mathrm{~h}$ post-exercise; $\mathrm{b}(\mathrm{p}<0.01)$ Pre-exercise $-8 \mathrm{~h}$ post-exercise.

Natural Killer Cytotoxic Activity

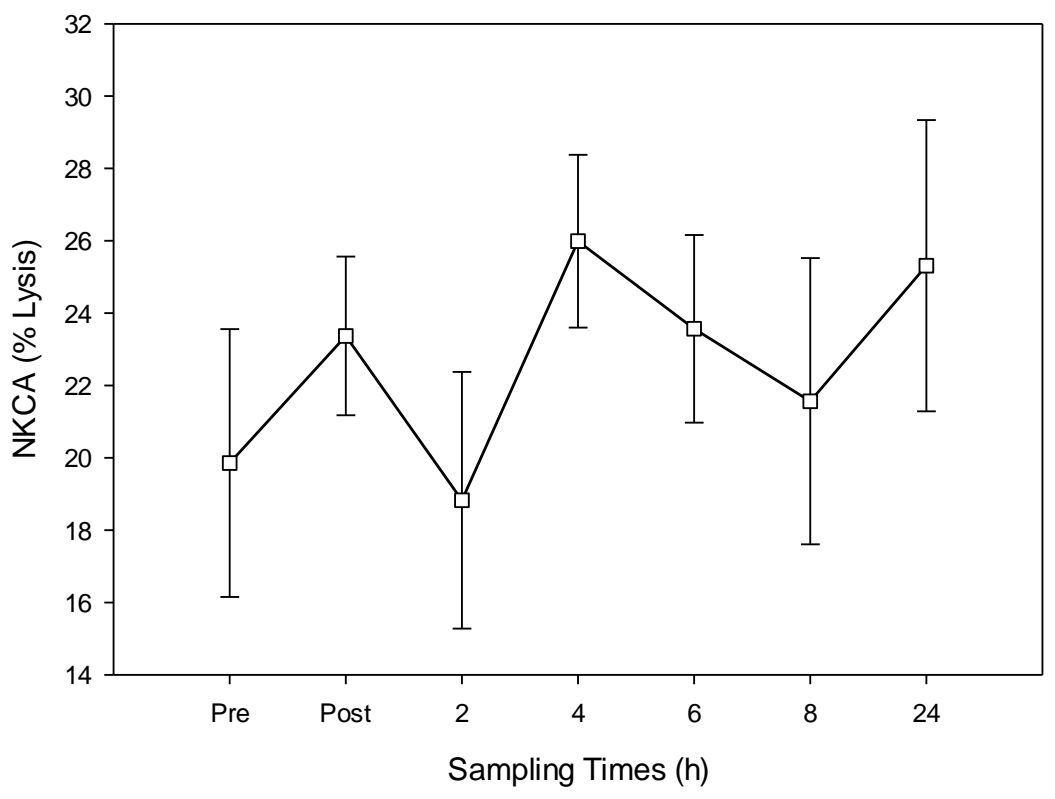

Figure 9: Changes in NKCA in response to an acute bout of exercise 
Natural Killer Cell Phenotype

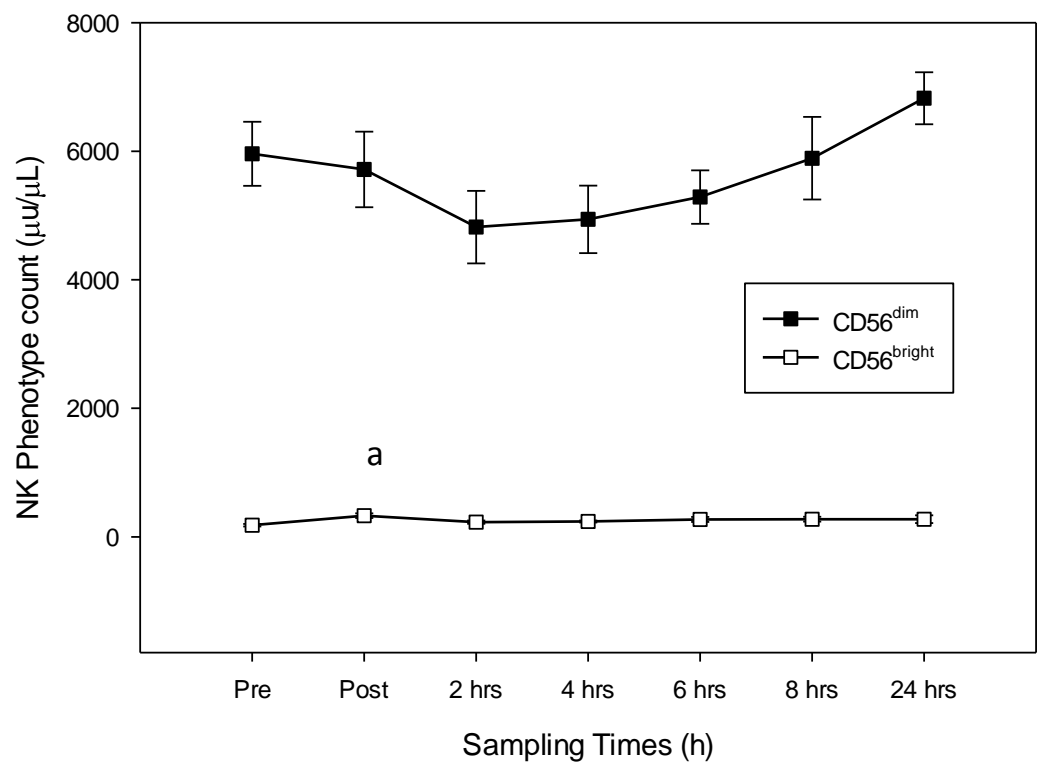

Figure 10: Changes in NK cell phenotype in response to an acute bout of exercise, a $(p<0.01)$ Pre-exercise - Immediately post-exercise.

\section{Eosinophils}

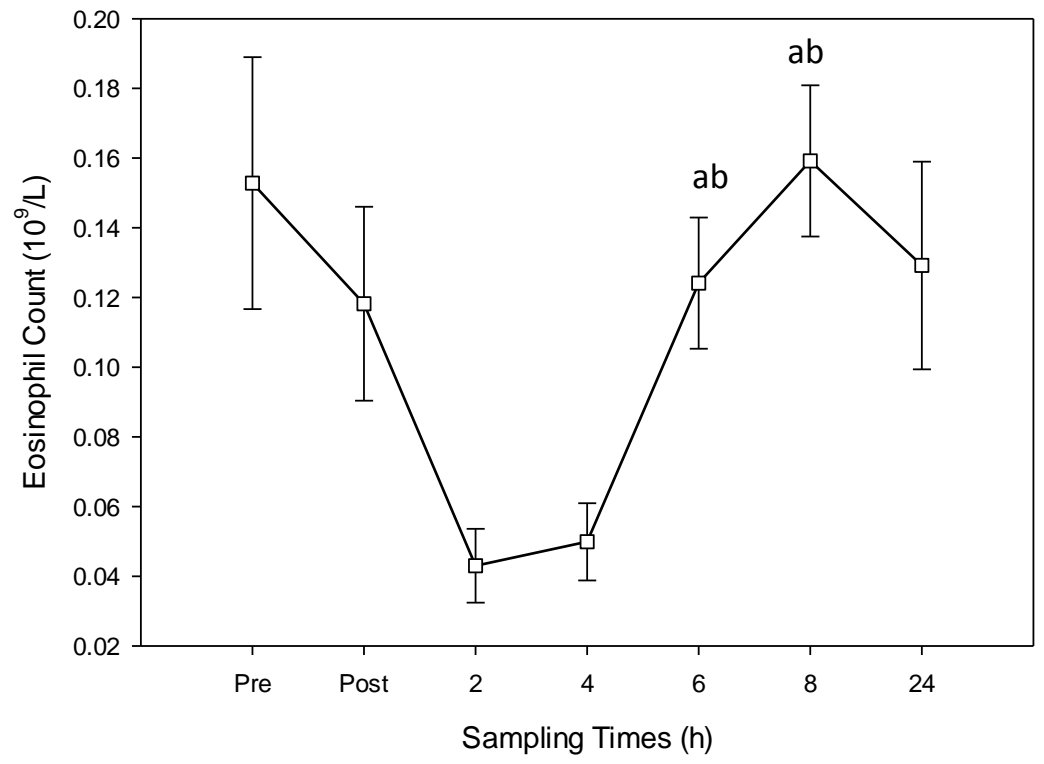


Figure 11: Changes in eosinophil concentration in response to an acute bout of exercise, $\mathrm{a}(\mathrm{p}<0.01) 2 \mathrm{~h}$ post-exercise $-6 \mathrm{~h}, 8 \mathrm{~h}$ post-exercise; $\mathrm{b}(\mathrm{p}<0.05) 4 \mathrm{~h}$ post-exercise $-6 \mathrm{~h}, 8 \mathrm{~h}$ postexercise

\section{Discussion}

The results from the present study provide further evidence to validate the 'open window' theory, by confirming the presence of lower immune cell numbers and function following an acute bout of endurance exercise. Collectively, the results from this study suggest that some aspects of immune function do not return to normal for several hours after exercise, which may have implications for resistance to URI.

Neutrophil counts increased significantly from pre- to immediately post- and $2 \mathrm{~h}$ post-exercise, and then decreased progressively thereafter. By $24 \mathrm{~h}$ post-exercise, neutrophil counts had returned to pre-exercise values. Increases in circulating neutrophil concentration have been reported previously $(8,13,43)$.

The results from this study where a 5-fold increase in neutrophil cell numbers was evident at $2 \mathrm{~h}$ post-exercise suggests that about $80 \%$ of neutrophils circulating during the post-exercise period were mobilised from the marginal pool and bone marrow $(13,18)$. The mechanism by which neutrophil counts increase and peak around $2 \mathrm{~h}$ after exercise has been discussed $(32,37)$, and suggests that circulating stress hormones may play a role in mobilising neutrophils. Increased release of growth hormone, epinephrine and norepinephrine at the onset of exercise may stimulate the initial increase in neutrophil numbers, as these hormones increase significantly during exercise (40). This neutrophilia is maintained following exercise lasting more than $1 \mathrm{~h}$ (19) by circulating serum cortisol, as seen in cross-country skiers performing maximal exercise (47). Additionally, cytokines IL-1 (27), IL-6 (12), and TNF- $\alpha$ (6) increase in response to an acute bout of endurance exercise in a post-exercise inflammatory response to muscle damage, eliciting an increase in neutrophil numbers (44).

Neutrophil phagocytic function did not significantly change until $2 \mathrm{~h}$ post-exercise, at which point it significantly decreased to $6 \mathrm{~h}$ post-exercise and $24 \mathrm{~h}$ post-exercise. This decrease in 
function following an acute bout of endurance exercise is supported by previous findings following prolonged exercise $(8,13,45)$. One possible reason for this response is that newly released neutrophils may have engulfed smaller amounts of $E$. coli bacteria. This explanation seems unlikely, however, because although neutrophil cell counts peaked at $2 \mathrm{~h}$ post-exercise, the phagocytic suppression was most evident at $6 \mathrm{~h}$ and $24 \mathrm{~h}$ post-exercise, suggesting that newly released neutrophils were not solely causing the phagocytic suppression. If lower phagocytic activity was due to greater numbers of immature neutrophils in the circulation, then it follows that phagocytic function decreased during the period when neutrophil counts peaked (i.e., $\sim 2 \mathrm{~h}$ post-exercise). Our finding that neutrophil phagocytic function remained low at $24 \mathrm{~h}$ postexercise may have implications for illness if athletes complete two bouts of exercise within $24 \mathrm{~h}$.

Neutrophil oxidative burst activity did not change significantly at any time point following the 2 $\mathrm{h}$ of exercise. These results parallel those of some (20,45), but not all studies $(8,22)$. Alterations in oxidative burst activity after exercise may depend on the balance of changes in stress hormones and cytokines that either stimulate or suppress oxidative burst activity.

Total lymphocyte counts increased significantly from pre- to immediately post-exercise, followed by a significant decrease below pre-exercise levels. Lymphocyte counts then significantly increased from $2 \mathrm{~h}$ post-, to $6 \mathrm{~h}$ and $8 \mathrm{~h}$ post-exercise; at $24 \mathrm{~h}$ post-exercise total lymphocyte counts had returned to pre-exercise levels. Total lymphocyte counts include T-cells $\left(\mathrm{CD}^{+}, \mathrm{CD}^{+}\right)$, B-cells $\left(\mathrm{CD} 19^{+}\right)$, and NK cells $\left(\mathrm{CD}^{+} 6^{+} / 56^{+}\right)$. This biphasic response of total lymphocytes to an acute bout of endurance exercise has been observed previously (21). The significant decrease in total lymphocyte numbers $2 \mathrm{~h}$ post-exercise supports the 'open window' theory. As this suppression in cell numbers may allow for an 'open window' of opportunity for pathogens, affecting the development of URI. The biphasic response of total lymphocytes numbers may be due to circulating stress hormones, including epinephrine, norepinephrine, and cortisol. It has been suggested that catecholamines induce the initial increase in lymphocyte numbers (35), whereas cortisol induces lymphopenia after exercise (36). This exercise-induced immunoregulation of the endocrine system on lymphocytes is seen in lymphocytes including $\mathrm{CD}^{+}$T-cells and NK cells (35).

The present study found no significant change in $\mathrm{CD}^{+} \mathrm{T}$-cell numbers from pre- to immediately post-exercise. However, there was a significant increase from immediately post- to $4 \mathrm{~h}$ post-and 
$6 \mathrm{~h}$ post-exercise. The increase in CD4+ T-cells may be due to an increase in interleukin 1 receptor antagonist (IL-1ra) which is found to increase about 2 hours after endurance exercise (33), and is known to have regulatory effects on $\mathrm{CD} 4^{+} \mathrm{T}$-cells (17). CD4 ${ }^{+} \mathrm{T}$-helper cells release an array of cytokines used to regulate immune response (28), including Type 2 cytokines (IL3, IL-5, and GM-CSF) which are involved in the activation of eosinophils $(25,26,48)$.

Eosinophil counts did not significantly change until $4 \mathrm{~h}$ post-exercise, at which point they significantly increased from $4 \mathrm{~h}$ to $8 \mathrm{~h}$ post-exercise. This increase in eosinophils mirrors that of $\mathrm{CD} 4^{+} \mathrm{T}$-cells, known to regulate eosinophils by release of specific regulatory cytokines including IL3, IL-5, and GM-CSF. These changes in eosinophil numbers may relate to airway inflammation in response to exercise. There have reportedly been difficulties in the categorising of URI symptoms between airway inflammation and infection following an acute bout of endurance exercise (5). It has been suggested that increases in eosinophil numbers, in addition to neutrophils and lymphocytes as possible factors causing airway inflammation (4).

NK cell numbers decreased significantly from pre-exercise to $4 \mathrm{~h}$ post-exercise and remained significantly below pre-exercise levels to $8 \mathrm{~h}$ post-exercise, returning to the pre-exercise levels by $24 \mathrm{~h}$. This study is the first to show suppression in NK cell numbers at $8 \mathrm{~h}$ after an acute bout of endurance exercise.

The decrease in circulating NK numbers observed in this study has been seen previously following an acute bout of endurance exercise $(30,46)$. This significant decrease in NK cell numbers in response to an acute bout of endurance exercise supports the 'open window' theory. A suppression in NK cell numbers, as part of the "first line of defence" against invading pathogens may have implications for athletes developing URI. Also, the suppression at $6 \mathrm{~h}$ and 8 $\mathrm{h}$ post-exercise is particularly relevant when considering repeat bouts of exercise. The effects of repeated exercise when NK cell numbers have not returned to resting levels may have significant implications for resting NK cell number following heavy training periods of endurance exercise in athletes. As with inadequate rest periods, chronic suppressions in NK cell counts and cell percentage changes have been observed in a previous study (15). This potentially may leave the immune system more susceptible to URI during recovery from exercise. 
As mentioned above, the regulation of NK cells is thought to reflect the combined effect of epinephrine and norepinephrine, which increase cell numbers (which was seen in this study, although not a significant increase). This is followed with a delayed onset of cortisol during exercise causing a decrease in numbers, which remains suppressed for a varying duration depending on severity of cortisol response (38). Additionally, although not clear, betaendorphins may play a mechanistic role after prolonged exercise (36).

NKCA did not significantly change over time in response to an acute bout of endurance exercise, which has not been seen in other studies following endurance exercise. This reflects no significant change in CD56 ${ }^{\mathrm{dim}}$ cytotoxic NK cell counts.

CD56 ${ }^{\text {bright }} \mathrm{NK}$ cells counts significantly increased from pre- to immediately post-exercise and remained unchanged compared with pre-exercise levels at each time point to $24 \mathrm{~h}$ post-exercise. No other study has examined NK cell phenotypes beyond immediately post-exercise. The ratio of CD56 ${ }^{\text {bright }}: \mathrm{CD}^{\mathrm{dim}} \mathrm{NK}$ cells significantly increased from pre-exercise to immediately postexercise. The mechanism underlying the significant change in CD56 ${ }^{\text {bright }}$ :CD56 ${ }^{\text {dim }}$ NK cell ratio may be due to regulation of IL-12 (released from dendritic cells and macrophages) which activates CD56 ${ }^{\text {bright }} \mathrm{NK}$ cells, and has been found to significantly increase in response to exercise (1).

Additionally, once CD56 $6^{\text {bright }} \mathrm{NK}$ cells are stimulated, an array of cytokines are released including TNF- $\alpha$ (7), which is known to act on neutrophils to increase cell numbers (6). This increase in $\mathrm{CD} 56^{\text {bright }} \mathrm{NK}$ cells matches the increase in neutrophil cell numbers and may have had a regulatory effect on neutrophil mobilisation.

Decreases in the number of some immune parameters were offset by increases in others. This causes difficulty in determining if the 'open window' theory is tangible when applying it to other parts of the immune system other than IgA levels, which is the only part of cellular immunity that has been linked to rates of URI (16).

\section{Conclusion}


Suppression in some immune variables was found in response to an acute bout of endurance exercise including; neutrophil phagocytic function, NK cell numbers, and total lymphocyte. These factors have not been linked to the incidence of URI in response to endurance exercise. However, they may provide a basis for future studies seeking to investigate if there is a relationship to the incidence of URI. More specifically, future studies could compare the relationship of soluble immune products as a potential mediator of resistance to infection following exercise.

\section{References}

1. Akimoto T, Akama T, Tatsuno M, Saito M, and Kono I. Effect of brief maximal exercise on circulating levels of interleukin-12. European Journal of Applied Physiology 81: 510-512, 2000.

\section{Aubry J, Blaecke A, Lecoanet-Henchoz S, Jeannin P, Herbault N, Caron G, Moine} $\mathbf{V}$, and Bonnefoy $\mathbf{J}$. Annexin $\mathrm{V}$ used for measured apoptosis in the early events of cellular cytotoxicity. Cytometry 37: 197-204, 1999.

3. Berman S, Eichelsdoerfer P, Yim D, Elmer G, and Wenner C. Daily ingestion of a nutritional probiotic supplement enhances innate immune function in healthy adults Nutrition Research 26: 454-459, 2006.

4. Bermon S. Airway inflammation and upper respiratory tract infection in athletes: is there a link? Exercise Immunology Review 7: 6-14, 2007.

5. Bonsignore M, Morici G, Vignola A, Riccobono L, Bonanno A, Profita M, Abate P, Scichilone N, Amato G, Bellia V, and Bonsignore G. Increased airway inflammatory cells in endurance athletes: what do they mean? Clinical \& Experimental Allergy 33: 14-21, 2003.

6. Brenner I, Natale V, Vasiliou P, Moldoveanu A, Shek P, and Shephard R. Impact of three different types of exercise on components of the inflammatory response. European Journal of Applied Physiology 80: 452-460, 1999.

7. Caligiuri M. Human natural killer cells. Blood 112: 461-469, 2008.

8. Chinda D, Nakaji S, Umeda T, Shimoyama T, Kurakake S, Okamura N, Kumae T, and Sugawara K. A competitive marathon race decreases neutrophil functions in athletes. Luminescence 18: 324-329, 2003. 
9. Cox A, Gleeson M, Pyne D, Callister R, Hopkins W, and Fricker P. Clinical and laboratory evaluation of upper respiratory symptoms in elite athletes. Clinical Journal of Sport Medicine 18: 438-445, 2008.

10. Cox A, Pyne D, Saunders P, Callister R, and Gleeson M. Cytokine responses to treadmill running in healthy and illness-prone athletes. Medicine and Science in Sport and Exercise 39: 1918-1926, 2007.

11. Davis J. Anaerobic threshold: a review of the concept and directions for future research. Medicine and Science in Sports and Exercise 17: 6-18, 1985.

\section{Drenth J, Uum SV, Deuren MV, Pesman G, Ven-Jongekrijg JVD, and Meer JVD.}

Endurance run increases circulating IL-6 and IL-1 ra but downregulates ex vivo TNF- $\alpha$ and IL-1 $\beta$ production. Journal of Applied Physiology 79: 1497-1503, 1995.

\section{Gabriel H, Müller H, Kettler K, Brechtel L, Urhausen A, and Kindermann W.}

Increased phagocytic capacity of the blood, but decreased phagocytic activity per individual circulating neutrophil after an ultradistance run. European Journal of Applied Physiology and Occupational Physiology 71: 281-284, 1995.

14. Gannon G, Rhind S, Suzui M, Shek P, and Shephard R. Exercise-Enhanced Natural Killer Cell Cytotoxic Capacity of Peripheral Blood Is Not Affected By the Opioid Antagonist Naltrexone. Medicine and Science in Sports and Exercise 29: 297, 1997.

15. Gleeson M, McDonald W, Cripps A, Pyne D, Clancy R, and Fricker P. The effect on immunity of long-term intensive training in elite swimmers. Clinical \& Experimental Immunology 102: 210-216, 1995.

\section{Gleeson M, McDonald W, Pyne D, Cripps A, Francis JL, Fricker P, and Clancy R.}

Salivary IgA levels and infection risk in elite swimmers. Medicine and Science in Sports and Exercise 31: 67-73, 1999.

\section{Greenbaum L, Horowitz J, Woods A, Pasqualini T, Reich E, and Bottomly K.}

Autocrine growth of CD4+ T cells. Differential effects of IL-1 on helper and inflammatory T cells. Journal of Immunology 140: 1555-1560, 1988.

18. Hack V, Strobel G, Rau J-P, and Weicker H. The effect of maximal exercise on the activity of neutrophil granulocytes in highly trained athletes in a moderate training period European Journal of Applied Physiology 65: 520-524, 1992. 
19. Halson S, Quod M, Martin D, Gardner A, Ebert T, and Laursen P. Physiological responses to cold water immersion following cycling in the heat. International Journal of Sports Physiology and Performance 3: 331-346, 2008.

20. Henson D, Nieman D, Nehlsen-Cannarella S, Fagoaga O, Shannon M, Bolton M, Davis J, Gaffney C, Kellin W, Austin M, Hjertman J, and Schilling B. Influence of carbohydrate on cytokine and phagocytic responses to $2 \mathrm{~h}$ of rowing. Medicine and Science in Sports and Exercise 32: 1384-1389, 2000.

21. Ibfelt T, Petersen E, Bruunsgaard H, Sandmand M, and Pedersen B. Exerciseinduced change in type 1 cytokine-producing CD8+ T cells is related to a decrease in memory $\mathrm{T}$ cells. Journal of Applied Physiology 93: 645-648, 2002.

22. Macha M, Shlafer M, and Kluger M. Human neutrophil hydrogen peroxide generation following physical exercise. The Journal of Sports Medicine and Physical Fitness 30: 412-419, 1990.

23. Mackinnon L, and Hooper S. Plasma glutamine and upper respiratory tract infection during intensified training in swimmers. Medicine and Science in Sports and Exercise 28: 285290, 1996.

24. Matthews C, Ockene I, Freedson P, Rosal M, Merriam P, and Hebert J. Moderate to vigorous physical activity and the risk of upper-respiratory tract infection. Medicine and Science in Sports and Exercise 34: 1242-1248, 2002.

25. Metcalf D, Begley C, Nicola N, and Johnson G. Quantitative responsiveness of murine hemopoietic populations in vitro and in vivo to recombinant multi-CSF (IL-3). Experimental Hematology 15: 288-295, 1987.

26. Metcalf D, Burgess A, Johnson G, Nicola N, Nice E, DeLamarter J, Thatcher D, and Mermod J. In vitro actions on hemopoietic cells of recombinant murine GM-CSF purified after production in Escherichia coli: comparison with purified native GM-CSF. Journal of Cellular Physiology 128: 421-431, 1986.

27. Moldoveanu A, Shephard R, and Shek P. Exercise elevates plasma levels but not gene expression of IL-1, IL-6, and TNF- in blood mononuclear cells. Journal of Applied Physiology 89: 1499-1504, 2000.

28. Murphy K, Travers P, and Walport M editors. Immunobiology. Garland Science, 2008. 
29. Nieman D. Exercise, infection and immunity. International Journal of Sports Medicine 15: S131-141, 1994.

30. Nieman D, Henson D, Gojanovich G, Davis J, Dumke C, Utter A, Murphy A, Pearce

S, McAnulty S, and McAnulty L. Immune Changes: 2h of Continuous vs. Intermittent Cycling. International Journal of Sports Medicine 28: 625-630, 2007.

31. Nieman D, Henson D, Gross S, Jenkins D, Davis J, Murphy E, Carmichael M,

Dumke C, Utter A, McAnulty S, McAnulty L, and Mayer E. Quercetin reduces illness but not immune perturbations after intensive exercise. Medicine and Science in Sports and Exercise 39: 1561-1569, 2007.

32. Ortega E. Neuroendocrine mediators in the modulation of phagocytosis by exercise: physiological implications. Exercise Immunology Review 9: 70-93, 2003.

33. Ostrowski K, Hermann C, Bangash A, Schjerling P, Nielsen JN, and Pedersen B. A trauma-like elevation of plasma cytokines in humans in response to treadmill running. Journal of Physiology 513: 889-894, 1998.

34. Pedersen B, and Bruunsgaard H. How physical exercise influences the establishment of infection. Sports Med 19: 393-400, 1995.

35. Pedersen B, Bruunsgaard H, Klokker M, Kappel M, MacLean D, Nielsen H, Rohde T, Ullum H, and Zacho M. Exercise-induced immunomodulation - possible roles of neuroendocrine and metabolic factors. International Journal of Sports Medicine 18: S2-S7, 1997.

36. Pedersen B, and Hoffman-Goetz L. Exercise and the immune system: regulation, integration, and adaptation. Physiological Reviews 80: 1055-1081, 2000.

37. Pedersen B, Rohde T, and Ostrowski K. Recovery of the immune system after exercise. Acta Physiologica Scandinavica 162: 325-332, 1998.

38. Pedersen B, and Toft A. Effects of exercise on lymphocytes and cytokines. British Journal of Sports Medicine 34: 246-251, 2000.

39. Peters E, Goetzsche J, Joseph L, and Noakes T. Vitamin C as effective as combinations of anti-oxidant nutrients in reducing symptoms of upper respiratory tract infections in ultramarathon runners. South African Journal of Sports Medicine 11: 23-27, 1996.

40. Rhind S, Gannon G, Shek P, Brenner I, Severs Y, Zamecnik J, Buguet A, Natale V, Shephard R, and Radomski M. Contribution of exertional hyperthermia to sympathoadrenalmediated lymphocyte subset redistribution. Journal of Applied Physiology 87: 1178-1185, 1999. 
41. Scharhag J, Meyer T, Gabriel H, Schlick B, Faude O, and Kindermann W. Does prolonged cycling of moderate intensity affect immune cell function? British Journal of Sports Medicine 39: 171-177, 2005.

42. Shinkai S, Shore $\mathbf{S}$, Shek $\mathbf{P}$, and Shephard $\mathbf{R}$. Acute exercise and immune function: Relationship between lymphocyte activity and changes in subset counts. International Journal of Sports Medicine 13: 452-461, 1992.

43. Sureda A, Cordova A, Ferrer M, Tauler P, Perez G, Tur J, and Pons A. Effects of Lcitrulline oral supplementation on polymorphonuclear neutrophils oxidative burst and nitric oxide production after exercise. Free Radical Research 43: 828-835, 2009.

44. Suzuki K, Totsuka M, Nakaji S, Yamada M, Kudoh S, Liu Q, Sugawara K, Yamaya K, and Sato K. Endurance exercise causes interaction among stress hormones, cytokines, neutrophil dynamics, and muscle damage. Journal of Applied Physiology 87: 1360-1367, 1999.

45. Takahashi I, Umeda T, Mashiko T, Chinda D, Oyama T, Sugawara K, and Nakaji S. Effects of rugby sevens matches on human neutrophil-related non-specific immunity. British Journal of Sports Medicine 41: 13-18, 2007.

46. Tvede N, Kappel M, Halkjaer-Kristensen J, Galbo H, and Pedersen B. The effect of light, moderate and severe bicycle exercise on lymphocyte subsets, natural and lymphokine activated killer cells, lymphocyte proliferative response and interleukin 2 response. International Journal of Sports Medicine 14: 1993.

47. Yamada M, Suzuki K, Kudo S, Totsuka M, Simoyama T, Nakiaji S, and Sugawara K. Effect of exhaustive exercise on human neutrophils in athlete. Luminescence 15: 15-20, 2000. 48. Yamaguchi Y, Suda T, Suda J, Eguchi M, Miura Y, Harada N, Tominaga A, and Takatsu K. Purified interleukin 5 supports the terminal differentiation and proliferation of murine eosinophilic precursors. Journal of Experimental Medicine 167: 43-56, 1988.

\section{Acknowledgements}

The authors acknowledge the help of the cyclists for giving up their time. Additional thanks to Prof Gregory Gass, Dr Neil Smart, James Keane, Siri Lauluten, Dag Hilland, Kien Kong and Rhys Christy for their technical assistance. This work was supported by grants from the Queensland Academy of Sport Centre of Excellence for Applied Sport Science Research and the Bond University Faculty of Health Sciences and Medicine. 